\title{
Formulating Western Fiction in Garrett Touch of Texas
}

\author{
Elisabeth Ngestirosa Endang Woro Kasih \\ Faculty of Art and Education, Universitas Teknokrat Indonesia, \\ Bandarlampung, Indonesia
}

\begin{abstract}
Western fiction as one of the popular novels has some common conventions such as the setting of life in frontier filled with natural ferocity and uncivilized people. This type of fiction also has a hero who is usually a ranger or cowboy. This study aims to find a Western fiction formula and look for new things that may appear in the novel Touch of Texas as a Western novel. Taking the original convention of Cooper's Leatherstocking Tales, this study also looks for the invention and convention of Touch of Texas by using Cawelti's formula theory. The study finds that Garrett's Touch of Texas not only features a natural malignancy against civilization, a ranger as a single hero, and a love story, but also shows an element of revenge and the other side of a neglected minority life. A hero or ranger in this story comes from a minority group, a mixture of white blood and Indians. The romance story also shows a different side. The woman in the novel is not the only one to be saved, but a Ranger is too, especially from the wounds and ridicule of the population as a ranger of mixed blood. The story ends with a romantic tale between Jake and Rachel. Further research can be done to find the development of western genre with other genres such as detective and mystery.
\end{abstract}

Keywords: fiction, formula, frontier, Western fiction, wilderness

Cite as: Woro Kasih, E. N. (2018). Formulating Western Fiction in Garrett Touch of Texas. Arab World English Journal for Translation \& Literary Studies, 2 (2).

DOI: http://dx.doi.org/10.24093/awejtls/vol2no2.10 